\title{
Homeobox Protein Hox-B6
}

National Cancer Institute

\section{Source}

National Cancer Institute. Homeobox Protein Hox-B6. NCI Thesaurus. Code C104337.

Homeobox protein Hox-B6 (224 aa, $25 \mathrm{kDa}$ ) is encoded by the human HOXB6 gene.

This protein is involved in embryonic pattern formation. 